\title{
Prevalences of Simian, Sydney and Suwon Creases and their Association with Each Other, Body Sides, Handedness, Sex and Anomalies/Diseases/Syndromes in a Population of Central India
}

\author{
Prevalencias de Pliegues Simiesco, de Sydney y de Suwon y su Asociación entre Ellos, Lados del Cuerpo, \\ Dominancia Manual, Sexo y Anomalías/Enfermedades/Síndromes en una Población de la India Central
}

"D. K. Sharma \& ${ }^{* *}$ Vandana Sharma

SHARMA, D. K. \& SHARMA, V. Prevalences of Simian, Sydney and Suwon creases and their association with each other, body sides, handedness, sex and anomalies/diseases/syndromes in a population of Central India. Int. J. Morphol., 29(3):1069-1075, 2011.

SUMMARY: The Simian and Sydney creases are variant palmar creases which have now drawn medical attention as their presence correlates strongly with numerous chromosomal anomalies and diseases. Works on these creases have been done on several human communities, racial and ethnic but no specific study is focussed out on the Indian populations. In this study 1000 Central Indian subjects (500 males and 500 females) aged between 5 to 70 years were randomly selected and examined by the authors. We found the prevalence of Simian, Sydney and Suwon creases in studied population of Central India is $14.4 \%, 3.6 \%$ and $2.4 \%$ respectively, which is a little higher than the figures for Asians and Caucasians claimed by earlier studies. There is no any association between these creases. The Simian crease is predominantly unilateral right side and associated with handedness. It is more common in males. The Sydney crease does not have unilateral or bilateral predominance and association with handedness but it is more common in females. The Suwon crease does not have unilateral or bilateral predominance and association with handedness but it is more common in males. There is no association of these creases with anomalies/diseases/syndromes. Conclusively this work draws attention to the importance of undertaking parallel investigations on every socio-cultural human group or population wherever possible.

KEY WORDS: Simian; Sydney; Suwon; Association; Syndrome.

\section{INTRODUCTION}

Three primary palmar creases/lines are the radial longitudinal crease, the proximal transverse crease, and the distal transverse crease which are called the life line, the head line and the heart line respectively in palmistry. The most common presentation is with 'one intersection' between primary palmar lines and no complete transversal lines. The second most common presentation is with 'no intersection' between primary palmar lines and no complete transversal lines (Figure 1).The important palmar crease variants include Simian, Sydney and Suwon creases.

The Simian crease is a single crease that extends across the palm, formed by the fusion of the two transverse palmar creases and so named as it resembles the usual condition of non-human simians (primates). The hands of simians are usually featured with multiple likewise horizontal lines that transverse the full palm. The Sydney crease is ex- tended proximal palmar crease or very long head line and so named as first described in Sydney, Australia. Recently a new Suwon crease with an incidence of $0.5 \%$ has been described as a single crease that extends across the palm, formed by the fusion of the two transverse palmar creases with an accessory proximal transverse crease and so named because it was first described in Suwon, Korea. In our opinion Suwon crease seems an extended distal transverse crease or heart line as Sydney crease is extended proximal transverse crease or head line.

The study of the palmar lines/creases traces back to the ancient civilizations of the Chinese and Indians as early as 3,000 years B.C. "In spite of the fact that creases for the last one century are under scientific consideration for want of an appropriate system for crease classification, the search is still on". The scientific study of dermal creases of the hands

\footnotetext{
* M.S. Anatomy, Ex. Associate Professor Anatomy, Walayar, Palakkad, Kerala, India.

*** Assistant Professor Anatomy, Gandhi Medical College, Bhopal, MP, India.
} 
and feet was first begun in 1823 by Evangelista Purkinje (Bali, 1994). Overtime, several studies have emerged which progressively show that dermal ridges of the hands and feet can be employed in the prediction of a range of medical conditions and diseases (Nazarabadi et al., 1997; Shiono, 1986; Lopuszanska \& Jankowska, 2001). Palmar creases are epidermal lines which produce typical or atypical patterns on the palmar surface of the hand. Simian and Sydney creases are anomalous palmar creases which have engendered medical attention because it is known that their presence correlate very strongly with several human chromosomal abnormalities and diseases (Loesch, 1983; Schaumann \& Opitz, 1991). "A Sydney line occurs where the proximal transverse crease extends beyond the midline axis of the fifth finger towards the ulnar border of the palm". The significance of the Sydney line can be related to various medical problems (such as: Down's syndrome, leukemia, Alzheimer dementia), and psychological problems (in general: developmental problems at young ages) (Purvis-Smith, 1972). Palmar crease configuration begins to develop about the 12 th week of gestation and results from the interplay of genetic and environmental factors during the early stage of ontogenesis (Lopuszanska \& Jankowska). Epidermal lines or dermatoglyphics analysis is now a valuable companion to other methods used for diagnosis of some genetic diseases such as phenyloketonuria and syndromes genetically determined e.g., Down, Turner or Klinefelter syndromes (Kava et al., 2004). The palm usually has three flexion creases sloping from an angle near the metacarpophalangeal joint of the index finger. Neither of the transverse creases extends entirely across the palm from the radial border to the ulnar boarder (Kava et al.). The occasional fusion of the proximal and distal creases, an event that occurs prior to the $12^{\text {th }}$ week of foetal life, creates a single palmar crease the Simian crea- se (Fig. 1) which extends entirely across the palm (Kamali, 1985). Infrequently both transverse creases are present but with only one of either completely crossing the palm resulting to a Sydney crease (Borbolla et al., 1980). Simian crease has been implicated in more than twenty human diseases/genetic disorders (Loesch). Sydney creases though very rare, is also associated with clinical conditions (Schaumann \& Opitz).

The presence of these creases do not necessarily signify abnormality, as it has been observed in some normal individual and some were exceptionally intelligent (Hernández, 1985; Lde Lestrange, 1969). Palm creases are helpful in revealing the anthropologic characteristics of the populations of different ethnic origins. For example, the frequencies of normal, Simian, and Sydney creases are different between Caucasians and Negroes (Dar et al., 1977).

\section{MATERIAL AND METHOD}

Total 1000 central Indian subjects (500 males and 500 females) aged between 5 to 70 years were randomly selected and examined by authors on both sides for the presence of the Simian, Sydney and Suwon creases with the help of method presented by Park et al. (2010) (Figures 2 and 3). Subjects whose father or mother was not of central Indian ethnic origin or with injury of hands were excluded from study. Unilateral or bilateral presence of any of these lines caused authors to record the age, sex, handedness and presence of anomalies/diseases/syndromes of that subject. Observations were finally analysed by Fisher's exact test. Significance level for all comparisons was set at $\mathrm{p}<0.05$.
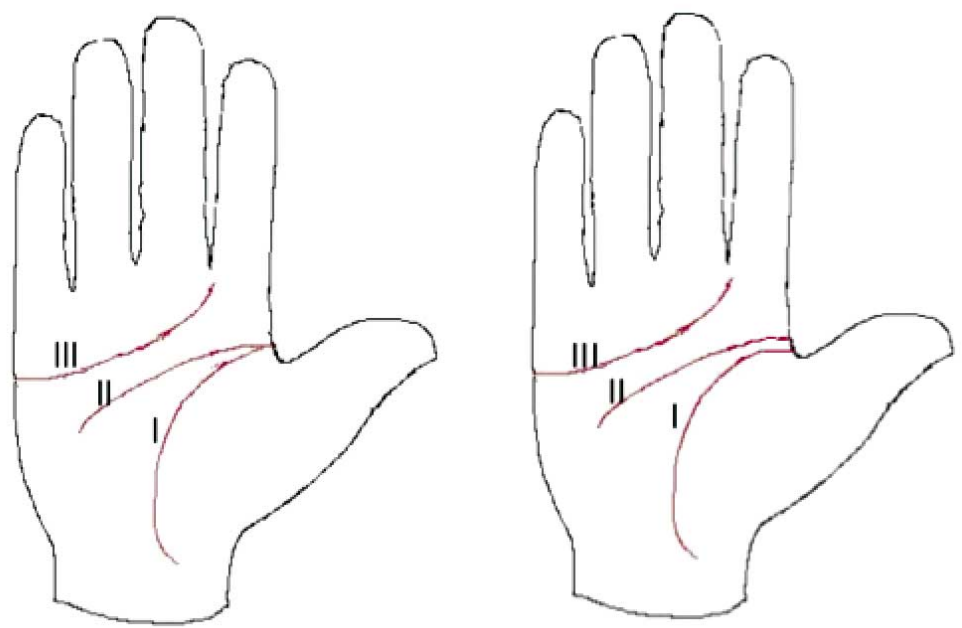

Fig. 1. Three Primary Palmar creases: I. Radial Longitudinal Crease. II. Proximal Transverse Crease. III. Distal Transverse Crease; and their most common and second most common presentations.

\section{RESULTS}

We found that the Simian crease is the most common variant palmar crease whereas the Sydney and Suwon creases are the second and third common variant palmar creases respectively. Though this study found three subjects with Simian crease in their one hand and Suwon crease on their other hand; and two subjects presented Sydney and Suwon creases in their different hands but no one presented Simian and Sydney both in different hands, however no any association could be established between these Simian, Sydney and Suwon creases. 
SHARMA, D. K. \& SHARMA, V. Prevalences of Simian, Sydney and Suwon creases and their association with each other, body sides, handedness, gender and anomalies/diseases/syndromes in a population of Central India. Int. J. Morphol., 29(3):1069-1075, 2011.

\section{DISCUSSION}

We found no association between these Simian, Sydney and Suwon creases. In this study the Simian crease out of its total presence in $14.4 \%$ subjects, showed $5.7 \%$ bilateral and $8.7 \%$ unilateral presences. Statistically unilateral presence was little more common than bilateral presence. The unilateral presence was more common on the right side (R: $5.7 \%$, L: $3 \%$ ) and most of them were righthanded persons so there was statistical association with handedness. Overall and unilateral presence of Simian crease were statistically little more common in males (M: 8.4\%, F: $6 \%$ and $\mathrm{M}: 5.4 \%$, F: $3.3 \%$ respectively) however no statistical significance was evident between male and female in bilateral presence (M: 3\%, F: 2.7\%). The Simian crease appears approximately in 1 out of 30 people or $4 \%$ of Caucasians and about $13 \%$ of all Asians on at least one hand. It is even rarer to have this line on both hands. At least fourteen chromosomal abnormalities are listed in the medical literatures that have a high correlation (up to 84\%) with the occurrence of a Simian Line. Down syndrome is one of these diseases due to a chromosome abnormality. Does that mean that every person with a Simian Line is likely to have something medically wrong with them? No! There are many people with Simian Lines that do not have more than the average medical problems (Rodrigues, 2009). Males are twice as likely as females to have this characteristic, and it tends to run in families. In its non-symptomatic form it is more common among Asians and Native Americans than among other populations. In some families there is a tendency to inherit the condition unilaterally that is on one hand only. Later, researchers found that both the Sydney and the Simian crease relate to a set of medical and psychological problems, including Down's syndrome, Alzheimer dementia, leukemia, and psychological developmental problems. This study showed prevalence of Simian line $14.4 \%$ which is little higher than the figures for Asians and Caucasians, claimed by earlier studies. Statistically unilateral presence was little more common than bilateral presence. Our findings are close to the figures for Chinese, Gypsies and Koreans but not in consonance to figures for Pygmies, Swiss, Germans, Nigerians etc shown in Table II and Figure 4 by Nazarabadi et al. and Lde Lestrange. This discrepancy can be explained by ethno-historic and geographic variations between different human populations (Arrieta et al., 1990, 1993). Dar et al. have earlier submitted that race, sex, and age are factors
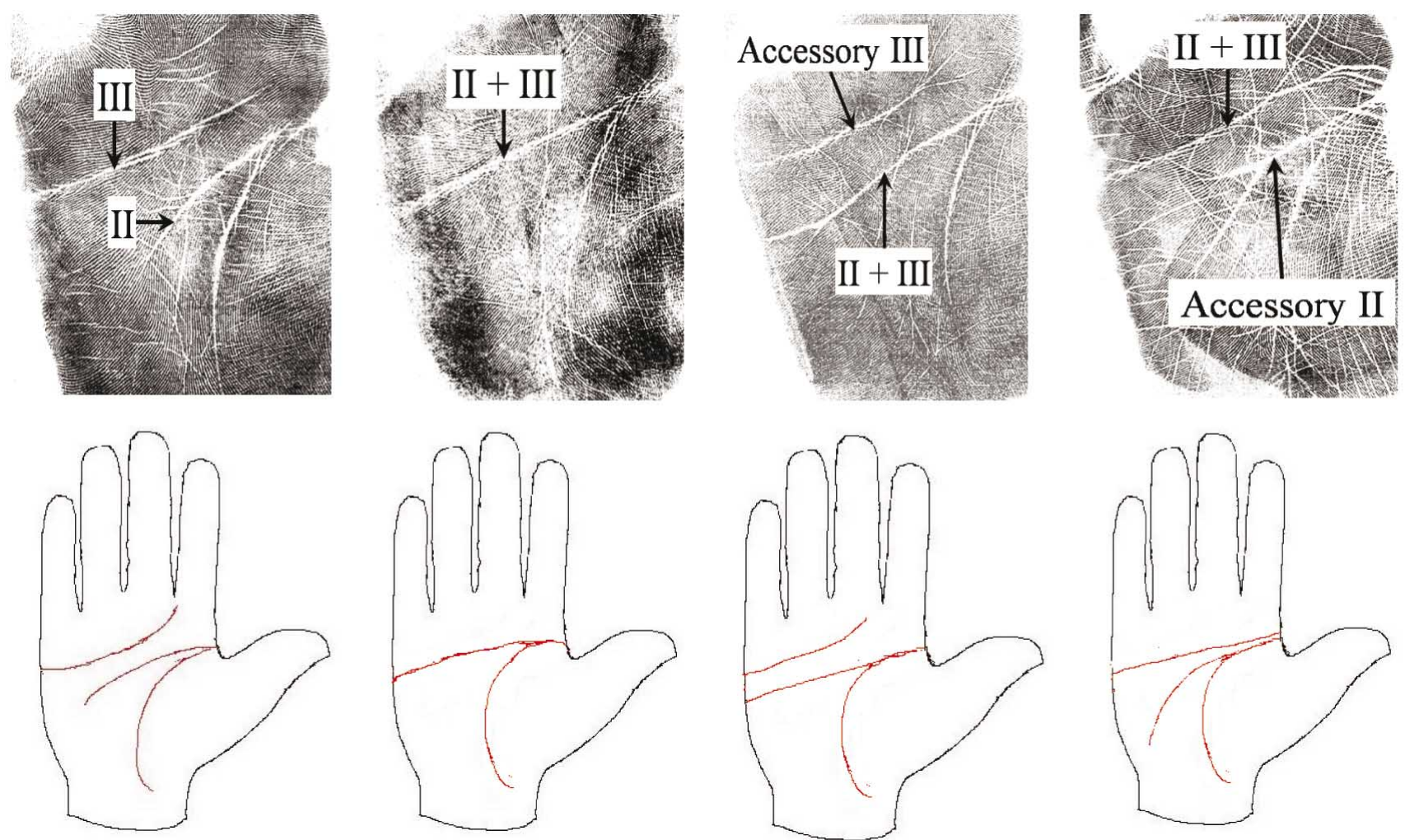

Fig. 2. Types of palmar creases based on the relationship between the proximal transverse crease (II) and distal transverse crease (III): Normal crease: II and III do not meet. Simian crease: II and III meet to cross the palm. Sydney crease: II and III meet, accompanied by accessory III. Suwon crease: II and III meet accompanied by accessory II. 
Normal
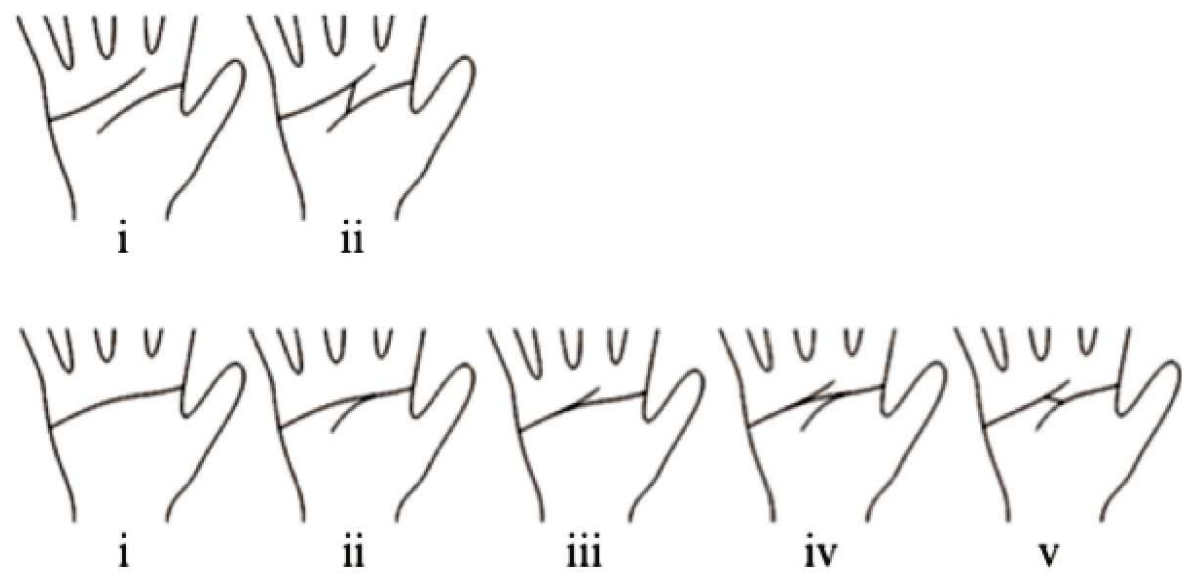

Simiat?

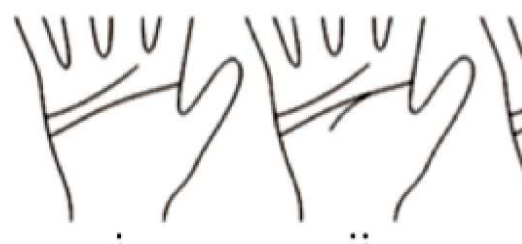

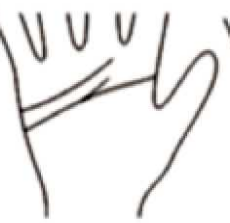

iii

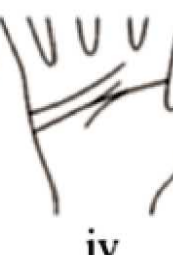

iv

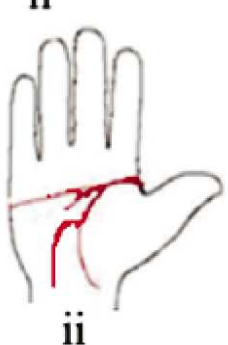

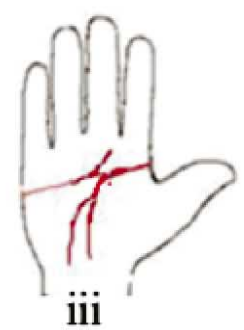

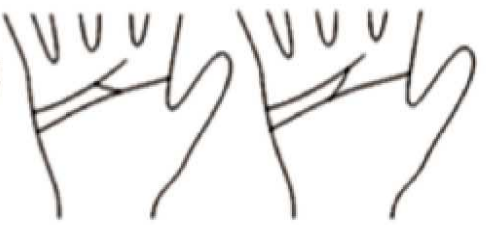

$\mathrm{V}$

vi
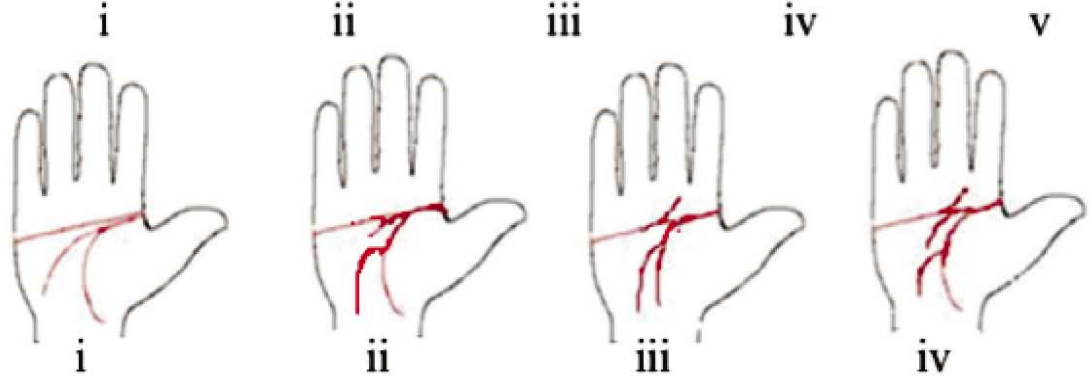

Suwon

Figure 3. Subtypes of Normal, Simian, Sydney and Suwon creases based on the branches of the proximal transverse crease (II) and distal transverse crease (III). Normal i: II and III do not meet absolutely. Normal ii: II and III meet by recurrent branches of II, III. Simian i: Branch of II or III does not exist. Simian ii: Proximal branch of II exists. Simian iii: Distal branch of III exists. Simian iv: Proximal branch of II and distal branch of III exist. Simian v: II and III meet by branches of II and III. Sydney i: Branch of II or III does not exist. Sydney ii: Proximal branch of II exists. Sydney iii: Distal branch of III exists. Sydney iv: Proximal branch of II and distal branch of III exist. Sydney v: II and accessory III meet by branches of II and accessory III. Sydney vi: II and accessory III meet by the recurrent branches of II and accessory III. Suwon i: Accessory III but branch of II or III does not exist. Suwon ii: Accessory III and branch of II exist. Suwon iii: Accessory III and branch of III exist. Suwon iv: Accessory III and branch of II and III exist.

that influence the expression of palmar crease patterns. Hence this lack of homogeny is not unusual, thus accentuating the importance of undertaking parallel study on every Human population where possible.

In this study the Sydney crease out of its total presence of $3.6 \%$ subjects, showed $1.9 \%$ bilateral and $1.7 \%$ unilateral presences. Statistically there was no association between bilateral and unilateral presences or between body sides and handedness. Overall, bilateral and unilateral presence were statistically more common in females (M: $0.9 \%, \mathrm{~F}: 2.7 \%$, M: 0.3 , F: $1.6 \%$ and M: $0.6 \%$, F: $1.1 \%$ respectively). This differs from those of the Orients (Lde Lestrange), but not with that of the Caucasian (Hernández). Arguments as regards to racial variation in Sydney crease prevalence need no emphases as it is uncommon. Although Ravindranath $e t$ $a l$ in their work mention: dermatoglyphics in rheumatoid arthritis shed a bit of controversy in reporting a high occurrence of Sydney crease in their normal control which was in contrast to established patterns (Hernández) and to our findings. They also recorded female preponderance, which favours our finding of female preponderance in overall, bilateral and unilateral presence of Sydney crease (Table I). 
SHARMA, D. K. \& SHARMA, V. Prevalences of Simian, Sydney and Suwon creases and their association with each other, body sides, handedness, gender and anomalies/diseases/syndromes in a population of Central India. Int. J. Morphol., 29(3):1069-1075, 2011.

Table I. In 1000 subjects (500 males and 500 females)

\begin{tabular}{|c|c|c|c|c|c|}
\hline Palmar lines & $\begin{array}{c}\text { Overall } \\
\text { (Male:Female) }\end{array}$ & $\begin{array}{c}\text { Bilateral } \\
\text { (Male:Female) }\end{array}$ & $\begin{array}{c}\text { Unilateral } \\
\text { (Male:Female) }\end{array}$ & $\begin{array}{l}\text { Right sided } \\
\text { (Male:Female) }\end{array}$ & $\begin{array}{c}\text { Left sided } \\
\text { (Male:Female) }\end{array}$ \\
\hline 1. Simian line & $144(84: 60)$ & $57(30: 27)$ & $87(54: 33)$ & $57(36: 21)$ & $30(18: 12)$ \\
\hline 2. Sydney line & $36 \quad(9: 27)$ & $19(3: 16)$ & $17(6: 11)$ & $8 \quad(3: 5)$ & $9 \quad(3: 6)$ \\
\hline 3. Suwon line & $24 \quad(17: 7)$ & $9 \quad(8: 1)$ & $15(9: 6)$ & $9 \quad(3: 6)$ & $6 \quad(6: 0)$ \\
\hline
\end{tabular}

Table II. Comparison of Simian crease prevalence with other known Populations prevalences.

\begin{tabular}{lc}
\hline Country / Region & Prevalence \\
\hline Nigeria Ijaws & 4.1 \\
Iranian & 2.5 \\
Pygmies & $34.7^{*}$ \\
Gypsies & $14.3^{*}$ \\
Chinese & $13^{*}$ \\
Koreans & $11.2^{*}$ \\
Kyushu Japanese & $9.2^{*}$ \\
Arabs \& Berbers & $7.9^{*}$ \\
Jew & 4.6 \\
Eastern Japanase & 4.0 \\
German s & 2.8 \\
Ainu & 2.2 \\
Dutch & $1.5^{*}$ \\
Eskimos & $1.3^{*}$ \\
Swiss & $1.2^{*}$ \\
Indian Central & $\mathbf{1 4 . 4}$ (Present study) \\
\hline
\end{tabular}

In this study the Suwon crease out of its total presence of $2.4 \%$ subjects, showed $0.9 \%$ bilateral and $1.5 \%$ unilateral presences. Statistically there was no association between bilateral and unilateral presences or between body sides and handedness. Overall and bilateral presence were statistically little more common in males (M: $1.7 \%, \mathrm{~F}: 0.7 \%$ and $\mathrm{M}$ : $0.8 \%, \mathrm{~F}: 0.1 \%$ respectively). In unilateral presence, no association could be established between sexes. Racial variation could not be studied due to lacking studies on Suwon crease as this crease is recently identified and classified.

There was no association between Simian, Sydney and Suwon creases with any significant anomalies/diseases/ syndromes that was evident.

Palm creases are of practical use because they can be analyzed quickly without physical pain, high costs, or age considerations (Caplan, 1990). Palm creases are helpful in revealing the anthropologic characteristics of the populations of different ethnic origins. For example, the frequencies of normal, simian, and Sydney creases are different between Caucasians and Negroes (Dar et al.).

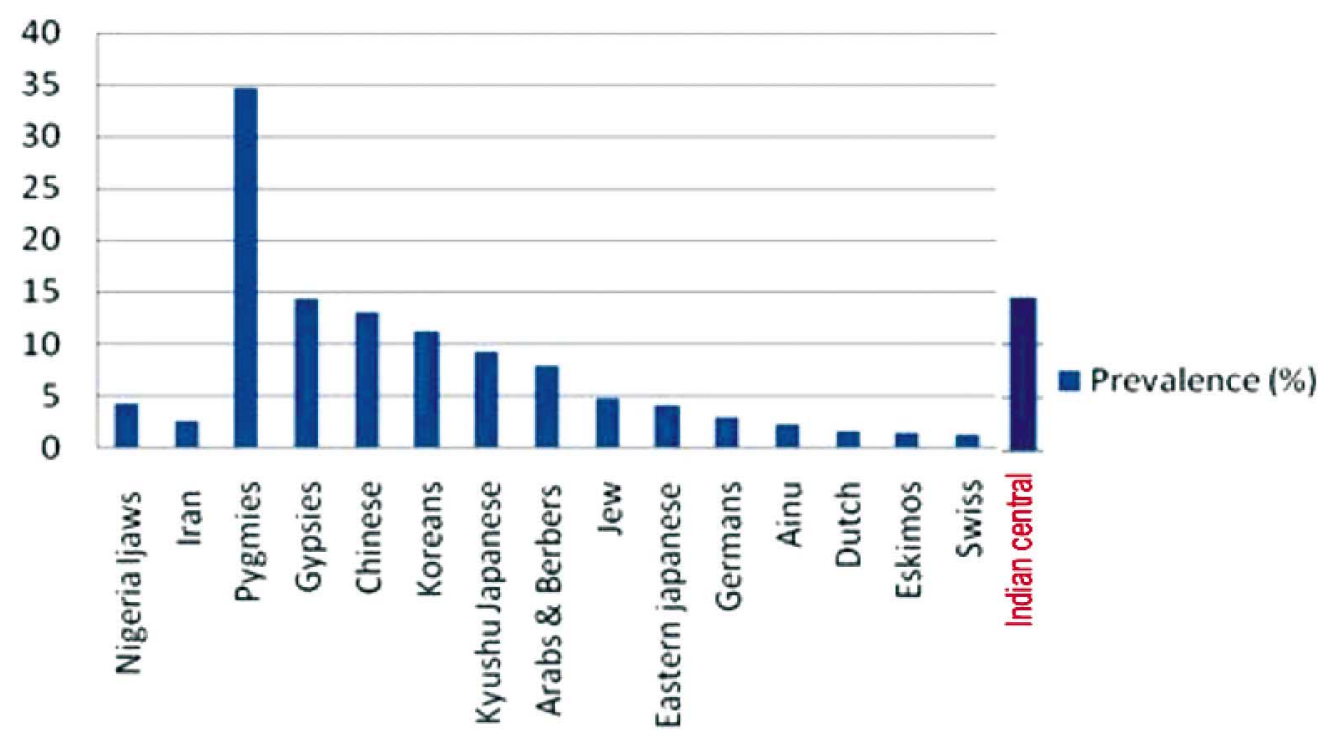

Fig. 4. Simian Crease Prevalence Rate (\%) of Diverse Human Populations. 
This discrepancy can be explained by ethno-historic and geographic variations between different human populations (Arrieta et al., 1990, 1993). Dar et al have earlier submitted that race, sex, and age are factors that influence the expression of palmar crease patterns. Hence this lack of homogeny is not unusual and accentuating the importance of undertaking parallel study on every Human population where possible. The submissions of Dar et al.,that dermatoglyphics polymorphism results from the co-operation of genetic, ethno-historic and environmental factors remains valid in explaining the lack of homogeny observed between various studies. However, rather paradoxical, dermatoglyphics pattern of patients with Down syndrome is not affected by ethnic or geographic factors (Borbolla et al.). The physical anthropological variations are normal occurrence amongst diverse human populations. It is noteworthy to have this in mind when interpreting prevalence values between two different human communities/populations (Oyinbo \& Fawehinmi, 2009).
In conclusion, we submit that the prevalence of Simian, Sydney and Suwon creases in a population of Central India is $14.4 \%, 3.6 \%$ and $2.4 \%$ respectively which is little higher than the figures for Asians and Caucasians, claimed by earlier studies. There is no association between these creases. The Simian crease is predominantly unilateral right side and associated with handedness. It is more common in males. The Sydney crease does not have unilateral or bilateral predominance and association with handedness but it is more common in females. The Suwon crease does not have unilateral or bilateral predominance and association with handedness but it is more common in males. There is no association of these creases with anomalies/diseases/syndromes. Conclusively this work draws attention and emphasis to the importance of undertaking parallel investigations in every socio-cultural human group or population wherever possible.

SHARMA, D. K. \& SHARMA, V. Prevalencias de pliegues simiesco, de Sydney y de Suwon y su asociación entre ellos, lados del cuerpo, dominancia manual, sexo y anomalías/enfermedades/síndromes en una población de la India central. Int. J. Morphol., 29(3):1069$1075,2011$.

RESUMEN: Los pliegues simiescos y de Sydney, son pliegues palmares variantes que en la actualidad han llamado la atención médica, ya que su presencia se relaciona estrechamente con numerosas anomalías cromosómicas y enfermedades. Investigaciones sobre estos pliegues se han realizado en diferentes comunidades humanas, raciales y étnicas, pero ningún estudio específico se centra sobre las poblaciones indígenas. En este estudio 1000 sujetos de la India central (500 hombres y mujeres 500) entre 5 y 70 años fueron seleccionados al azar y examinados. Se encontró que la prevalencia de los pliegues Simiescos, de Sydney y de Suwon de la población estudiada es de $14,4 \%, 3,6 \%$ y $2,4 \%$ respectivamente, mayor que los porcentajes en asiáticos y caucásicos. No hay ninguna asociación entre estos pliegues. El pliegue simiesco es predominantemente unilateral derecho y se asocia con dominancia manual. Es más común en los hombres. El pliegue de Sydney no tiene predominio unilateral o bilateral, ni asociación con dominancia manual, pero es más común en las mujeres. El pliegue de Suwon no tiene predominio unilateral o bilateral, ni asociación con dominancia manual, pero es más común en los hombres. No existe ninguna asociación de estos pliegues con anomalías/enfermedades/síndromes. Se concluye la importancia de realizar investigaciones paralelas en todos los grupos humanos o socio-culturales de la población siempre que sea posible.

PAlabraS ClaVE: Pliegue Simiesco; Pliegue de Sydney; Pliegue de Suwon; Asociación; Síndrome.

\section{REFERENCES}

Arrieta, M. I.; Criado, B.; Martinez, B.; Lobato, M. N.; Gil, A. \& Lostao, C. M. Fluctuating dermatoglyphic asymmetry: genetic and prenatal influences. Ann. Hum. Biol., 20(6):557-63, 1993.

Arrieta, M. I.; Martinez, B.; Simon, A.; Salazar, L.; Criado, B. \& Lostao, C. M. Quantitative and qualitative finger dermatoglyphics in the Basque Valley of Urola, Spain. Anthropol. Anz., 48(1):65-84, 1990.

Bali, R. S. Anthropology Of Crease Morphogenesis: A Scientific Analysis. New Delhi, Concept Publishing Company, 1994. p.127.
Borbolla, L.; Guerra, D. \& Bacallao, J. Dermatoglyphics in Cuban Mongols. Acta Paediatr. Acad. Sci. Hung., 21(23):107-21, 1980.

Caplan, R. M. How fingerprints came into use for personal identification. J. Am. Acad. Dermatol., 23(1):109-14, 1990.

Dar, H.; Schmidt, R. \& Nitowsky, H. M. Palmar crease variants and their clinical significance: a study of newborns at risk. Pediatr. Res., 11(2):103-8, 1977.

Hernández, M. Palmar creases in Spaniards. Anthropol. Anz., 43(2):187-90, 1985. 
SHARMA, D. K. \& SHARMA, V. Prevalences of Simian, Sydney and Suwon creases and their association with each other, body sides, handedness, gender and anomalies/diseases/syndromes in a population of Central India. Int. J. Morphol., 29(3):1069-1075, 2011.

Kamali, M. S. Simian crease polymorphism among fifteen Iranian endogamous groups. Anthropol. Anz., 43(3):21725,1985 .

Kava, M. P.; Tullu, M. S.; Muranjan, M. N. \& Girisha, K. M. Down syndrome: Clinical profile from India. Arch. Med. Res., 35(1):31-5, 2004.

Lde Lestrange, M. T. The transverse crease in Europe: Index and comparative study of different samples cited in the literature. Am. J. Phys. Anthropol., 30(2):173-82, 1969.

Loesch, D. L. Quantitative Dermatoglyphics: Classification, genetics and pathology. Oxford, Oxford Medical Publication, 1983.

Lopuszanska, M. \& Jankowska, E. A. Dermatoglyphic morphology in some diseases. Pol. Merkur. Lekarski, 11(63):282-6, 2001.

Nazarabadi, M. H.; Roofian, R.; Abutorabil, R. \& Hosseini, H. B. Dermatoglyphic Assessment in Down and Klinefelter Syndromes. Iran J Med Sci; 32(2):105-9, 2007.

Oyinbo, C. A. \& Fawehinmi, H. B. Prevalence of Simian and Sydney creases in the Ijaws of South-South Nigeria. The Internet Journal of Biological Anthropology, 3(2), 2009. Avalaible in: http://www.ispub.com/journal/ the_internet_journal_of_biological_anthropology/ volume_3_number_2_59/article/prevalence-of-simianand-sydney-creases-in-the-ijaws-of-south-south-nigeria1.html

Park, J. S.; Shin, D. S.; Jung, W. \& Chung, M. S. Improved analysis of palm creases. Anat. Cell Biol., 43(2):16977, 2010.

Purvis-Smith, S. G. The Sydney line: a significant sign in Down's syndrome. Aust. Paediatr. J., 8(4):198-200, 1972.

Rodrigues, L. Secrets of Hand Analysis. $2^{\text {nd }}$ Ed., 2009. Avalaible in: http://handanalysis.com/

Schaumann, B. A. \& Opitz, J. M. Clinical aspects of Dermatoglyphics. Birth Defects Orig. Artic. Ser., 27(2):193-228, 1991.

Shiono, H. Dermatoglyphics in medicine. Am. J. Forensic Med. Pathol., 7(2):120-6, 1986.
Correspondence to:

Dr. D. K. Sharma

M.S. Anatomy

Ex. Associate Professor Anatomy

KIMS (Karpaga Vinayaga Institute of Medical Science)

Kanchipuram - Tamilnadu

INDIA

Email: dhyanesh.sharma@gmail.com

Received: 15-03-2011

Accepted: 11-04-2011 